\title{
DESIGNING BRI ATM SECURITY SYSTEM PROTOTYPE WITH ARDUINO 37 SENSOR BASED ON ARDUINO MICROCONTROLLER
}

\author{
Nurdi, Firdausyi Aulia \\ Multimedia \& Network Engineering \\ State Polytechnic of Jakarta
}

\begin{abstract}
In today's Modern World, Autonomous Systems plays an Important Role in our day to day Life. As the Social Computerization and Automation have drastically increased, it can be seen evidently where the number of ATM Centers increases rapidly. Over past few years - "90\% of Crimes in ATM centers in the form of Robbery". This issue poses a serious threat to both Bank Management and Civilians. In this paper, a more recent security system was created for ATM machines. This monitoring system will monitor 24 hours a day, detect suspicious behaviors around the ATM machine and send hazard warning notifications.
\end{abstract}

Index Terms - Internet of Things, Arduino Mega 2560, ATM.

\section{INTRODUCTION}

o you know that ATM crime can now be done by only using a match? According to news reported from the

Tempo Metro website, there are four modes of ATM machine burglary that often occur in Indonesia. The perpetrators of crime will prop up the mouth of the ATM machine with a matchstick or toothpick which will cause the victim's ATM card to not be able to get out. In present scenario, ATM has become one of the most important facilities in our day to day life. This facility enables us to withdraw the money from the authorized account at any time. Security is the major aspect, as the need of ATM is increasing day by day.

The aforementioned cases are the background of the Department of IoT and Automation to make products to monitor ATM crime for Bank BRI machines. This monitoring system will monitor 24 hours a day, detect suspicious behaviors around the ATM machine and send hazard warning notifications. The BRI ATM security monitoring system is assembled using Arduino 37 sensors with the Arduino UNO microcontroller. Data transmission is done using a Wi-Fi module.

\section{SYSTEM MODELING}

The system used for monitoring ATM machines from suspicious events. Then the appropriate methodology is needed so that the expected results can be achieved. Bank BRI's ATM security monitoring system is designed using several Arduino 37 sensor components, including:

\section{- $\quad$ Real Time Clock Sensor}

Showing time in the form of date, month, year and hour in sending data from Arduino to PT. Astra Graphia Information Technology. This RTC sensor will be placed inside the ATM machine.

- $\quad$ Arduino KY-017 Mercury Open Optical Module as Tilt Sensor

Detect a significant slope from the BRI ATM machine. Arduino Sensor KY-017 Mercury Open Optical Module that will be used as a Tilt Sensor will be placed in the base ATM machine.

- Arduino KY-017 Mercury Open Optical Module as Shock Sensor

Detect large and strong vibrations from the BRI ATM machine. Arduino KY-017 Mercury Open Optical Module that will be used as this Sensor Shock will be placed inside the top ATM machine.

\section{- $\quad$ Arduino KY-013 Temperature Sensor Module}

Detects a significant temperature increase in the room around the BRI ATM. Arduino KY-013 Temperature Sensor Module will be placed outdoors because the main point detected is the room around the ATM machine.

- $\quad$ Smoke Sensor (MQ5)

Detect the presence of suspicious smoke from in the room around the BRI ATM. Smoke Sensor (MQ5) will be placed outdoors because the main point detected is the room around the ATM machine.

\section{A. System Components}




\section{- Buzzer}

Provides notifications in the form of audio when one of the sensors used detects a suspicious event. The buzzer will be placed inside the top ATM machine.

- $\quad$ Arduino Mega 2560

Arduino Mega 2560 will be used as a power supply because it has a pin that can provide voltage for connected components or circuits. GND and 5V pins will be jumped using the project board.

\section{B. Scheme and system sequence}

The sensors used will be designed according to the user requirements set in the first week. Following is the scheme and explanation of the series of sensors used for the crime monitoring system project at the BRI Bank ATM machine.

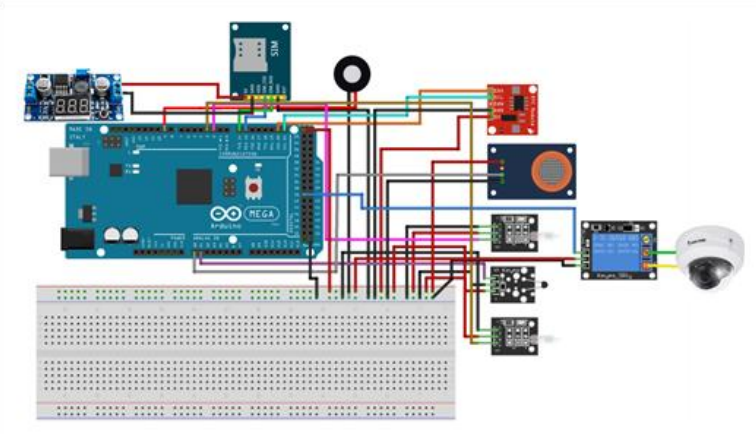

C. The series and program of each components

\section{- $\quad$ Real Time Clock}

RTC DS 1302 has four pins that will be connected to Arduino, namely; GND Pin: Ground on Arduino, VCC: 5V pin on Arduino, SCL Pins: Arduino SCL Pins, SDA Pin: Arduino SDA Pin.

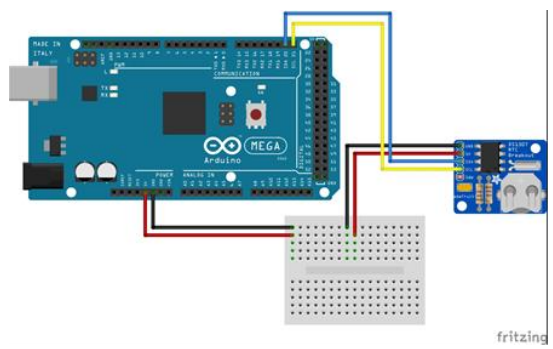

Do define the RTC sensor at the beginning of the program. This RTC sensor uses number 7 digital pin. Then, do a name for the RTC which will be used in the crime monitoring system project program on this BRI ATM machine. Then make a program to display information on the date, month and year when sending data to the PT server. Astra Graphia Information Technology. In addition to displaying the date, month and year, also make a program to display the hours, minutes and seconds when sending data to the PT server. Astra Graphia Information Technology. Then enter the two programs above into the raw_data format in the form of JSON, which is the format for sending data to the server owned by PT Astra Graphia Information Technology.

- $\quad$ Arduino KY-017 Mercury Open Optical Module as Tilt Sensor

Arduino KY-017 Mercury Open Optical Module has three pins that will be connected to Arduino, namely; Pin -: Ground on Arduino, Middle pin: $5 \mathrm{~V}$ on Arduino, Pin S: Arduino 3 Digital Pin.

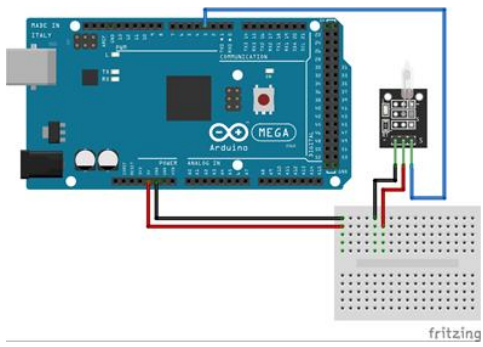

Perform define Arduino KY-017 Mercury Open Optical Module which will be used as a tilt sensor at the beginning of the program, in this program tilt the sensor using digital pin number 3 . Then create a program that will display the status of the tilt sensor. If the tilt sensor does not detect a suspicious slope, the system will issue a status of "TILT OFF" and if the tilt sensor detects a suspicious slope, the system will issue a status of "TILT ALERT". After that, create a program that will display the value of the tilt sensor. The output that comes out of the tilt sensor is in the form of boolean data. If the status is "TILT ALERT", then the value is " 1 " and if the status is "TILT OFF", then the value is "0". Then, enter the two programs above on raw_data which will be sent to the PT Astra Graphia Information Technology server.

- Arduino KY-017 Mercury Open Optical Module as Shock Sensor

Arduino KY-017 Mercury Open Optical Module has three pins that will be connected to Arduino, namely; Pin -: Ground on Arduino, Middle pin: $5 \mathrm{~V}$ on Arduino, Pin S: Arduino 3 Digital Pin.

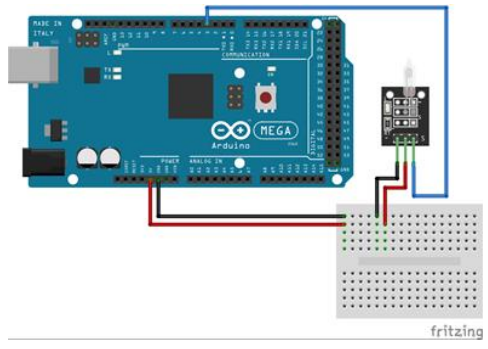

First, define Arduino KY-017 Mercury Open Optical Module which will be used as a shock sensor at the beginning of the 
program, in this program the sensor shock uses number 2 digital pin. Then create a program that will display the status of the sensor shock. If the shock sensor does not detect large and fast vibrations, the system will issue a status of "SHOCK OFF" and if the shock sensor detects a large and fast vibration, the system will issue a "SHOCK ALERT" status. After that, create a program that will display the value of the sensor shock. The output that comes out of the shock sensor is in the form of boolean data. If the status is "SHOCK ALERT", then the value is "1" and if the status is "SHOCK OFF", the value is "0". Then, enter the two programs above on raw_data which will be sent to the PT Astra Graphia Information Technology server.

\section{- Arduino KY-013 Temperature Sensor Module}

Arduino KY-013 Temperature Sensor Module has three pins that will be connected to Arduino, namely; Pin -: Ground on Arduino, Middle pin: 5V on Arduino, Pin S: A5 Arduino Analog Pin.

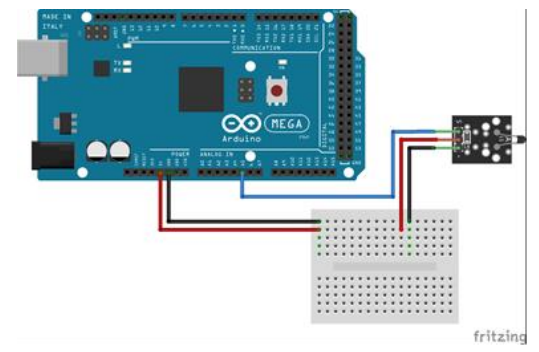

Definition of Arduino KY-013 Temperature Sensor Module at the beginning of the program, in this program use analog pin number A1. Then, create a program that will display the status of the Arduino KY-013 Temperature Sensor Module. If the temperature sensor does not detect a significant temperature rise, the system will issue a "NORMAL TEMPERATURE" status and if the temperature sensor detects a significant temperature rise, the system will issue a "TEMPERATURE ALERT" status.

In this project it was determined that the normal limit of temperature in the BRI ATM machine room was 32 degrees Celsius. Next make a program that will display the value of Arduino KY-013 Temperature Sensor Module. In this program, you need a formula to convert temperatures from Fahrenheit to Celsius. 10000 is a provision for dividing voltage. Whereas R1 is the temperature resistance calculated. "Analogval" is the size of Vo, which is a determination of 468. Then, the measurement of the degree of temperature with the temperature of the sensor can be calculated by the SteinhartHart equation.

Data output from Arduino KY-013 Temperature Sensor Module is the temperature in Fahrenheit units. Then, the formula $\mathrm{T}$ and $\mathrm{Tc}$ above can be used to convert these temperature units. Programming value for Arduino KY-013 Temperature Sensor Module. After converting the temperature, the next step is to declare the above programming into raw_data which will be sent to the PT Astra Graphia Information Technology server.

\section{- Smoke Sensor}

The MQ5 sensor has four pins that will be connected to Arduino, namely; GND Pin: Ground on Arduino, VCC: 5V pin on Arduino, SCL Pins: Arduino SCL Pins and SDA Pin: Arduino SDA Pin.

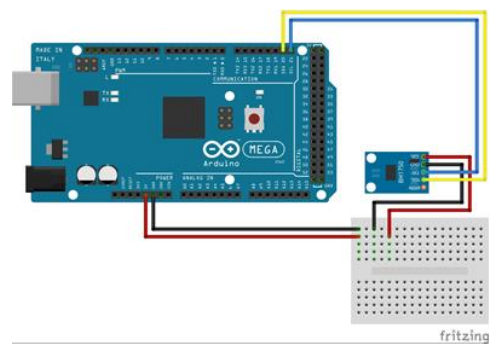

Define the pin for smoke sensor (MQ-5) at the beginning of the program, in this project using analog pin number A0. Next is the declaration of the smoke sensor which will be the input sensor in the void setup () function. Then, create a program to display the status of the smoke sensor. Experiments have been carried out on this smoke sensor to determine the normal point of a room without gas. The result of the experiment is 150 is the normal point of a room without gas. If the sensor detects a gas increase in a room of more than 150, the system will issue a "GAS ALERT" status and if the sensor does not detect an increase in gas in the room, the system will issue a "GAS OFF" status.

Then create a program to display the value of the smoke sensor. Use float data types because the data displayed is not an integer. Finally, add the above program to raw_data which will be sent to the PT Astra Graphia Information Technology server.

\section{- Buzzer}

The buzzer has two pins that will be connected to Arduino, namely: Pin with black cable: Ground on Arduino and Pin with red cable: $5 \mathrm{~V}$ on Arduino.

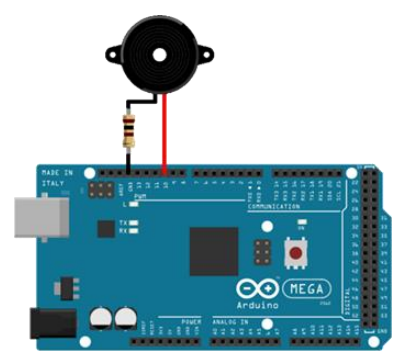


Define the pins used by the buzzer. In this project, the buzzer uses a digital number 9 pin. Then declare that the buzzer is an output sensor because this sensor will issue audio for danger notifications. After that, create a buzzer_trigger function to output audio when one of the sensors detects suspicious activity. "True" indicates that the buzzer is on. This project uses the millis function so that all sensors and modules that have a crime monitoring system project on BRI ATM machines are always running.

Make buzzer_handler function to turn off audio from the buzzer. The "true" function indicates that the buzzer will output audio, that is $(9,698)$ or $(9,880)$. However, if the function is "false", the buzzer will stop the audio, ie (9). When buzzerison has the status of "true", the buzzer will output audio and data sent to the server within one second per data. However, if buzzerison has the status of "false", the buzzer will stop the audio and the data will be sent to the server within 10 seconds per data.

\section{FINAL RESULT}

The form of output from the above programming in the serial monitor is as follows:

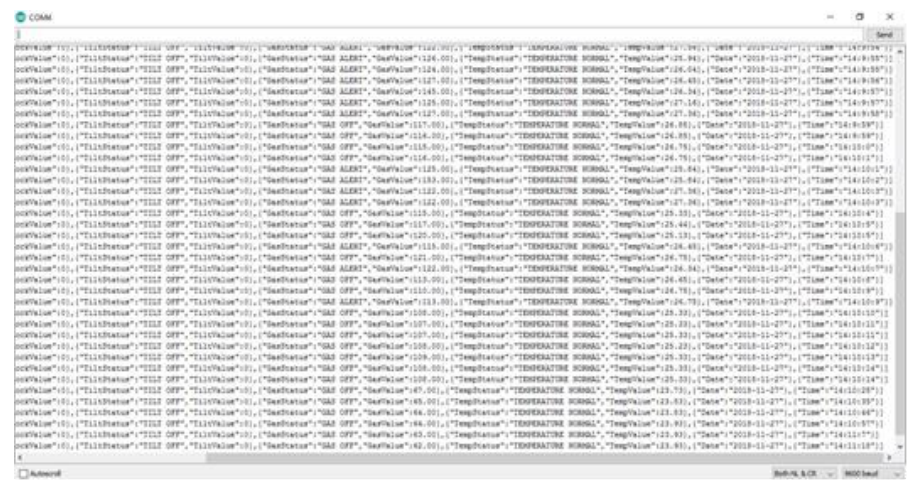

The serial monitor will display a TILT ALERT notification if there is a significant slope, displaying SHOCK ALERT if there is a significant vibration, displaying the GAS ALERT notification if there is a significant increase in gas and displaying the TEMPERATURE ALERT notification if the temperature rises significantly. In addition, the serial monitor also displays the date, month, year and time when raw_data is JSON.

The following are some photos from the Bank BRI ATM monitoring system prototype, namely:

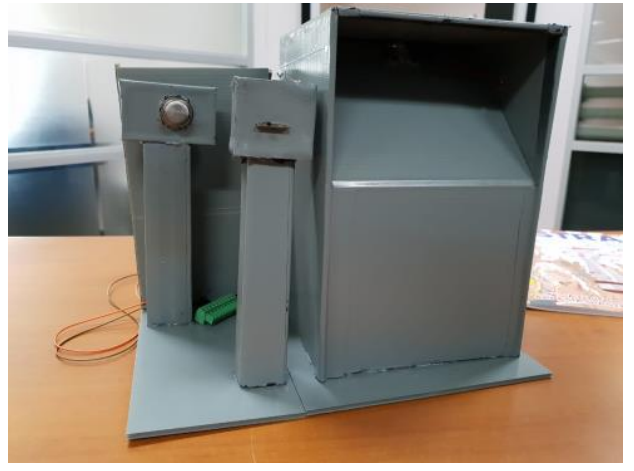

This is the front view of the BRI Bank ATM monitoring system prototype.

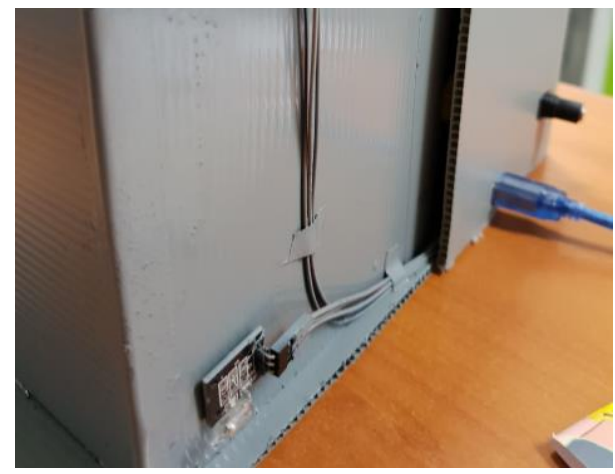

Tilt sensors are placed on the bottom side of this BRI Bank ATM monitoring system prototype.

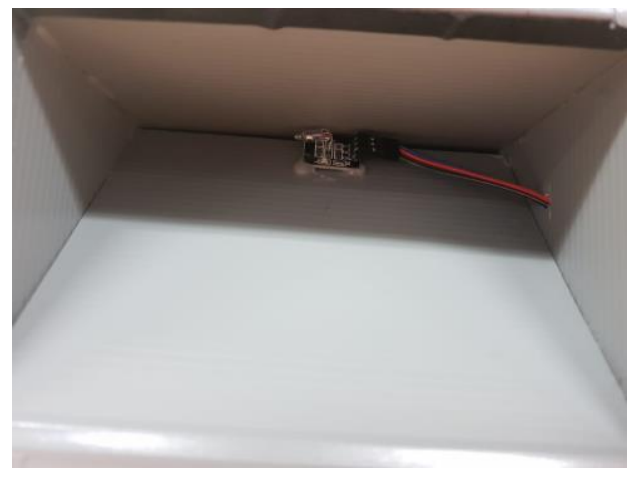

The shock sensor is placed on the top (roof) of the BRI Bank ATM monitoring system prototype.

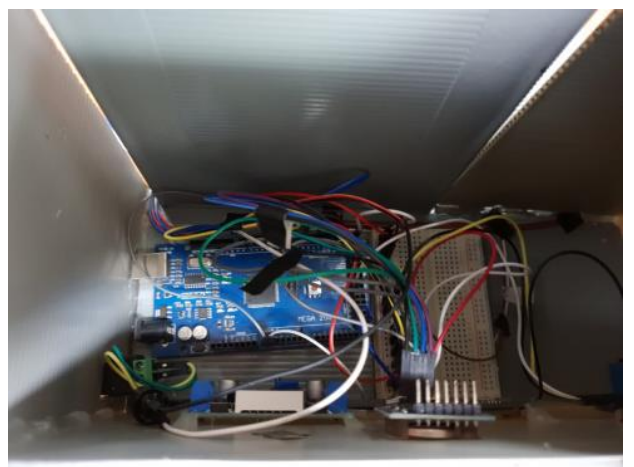


Buzzer, Real Time Clock and Wifi Module are placed in the security system prototype for Bank BRI ATMs. The Arduino Mega 2560 microcontroller is also placed in this prototype.
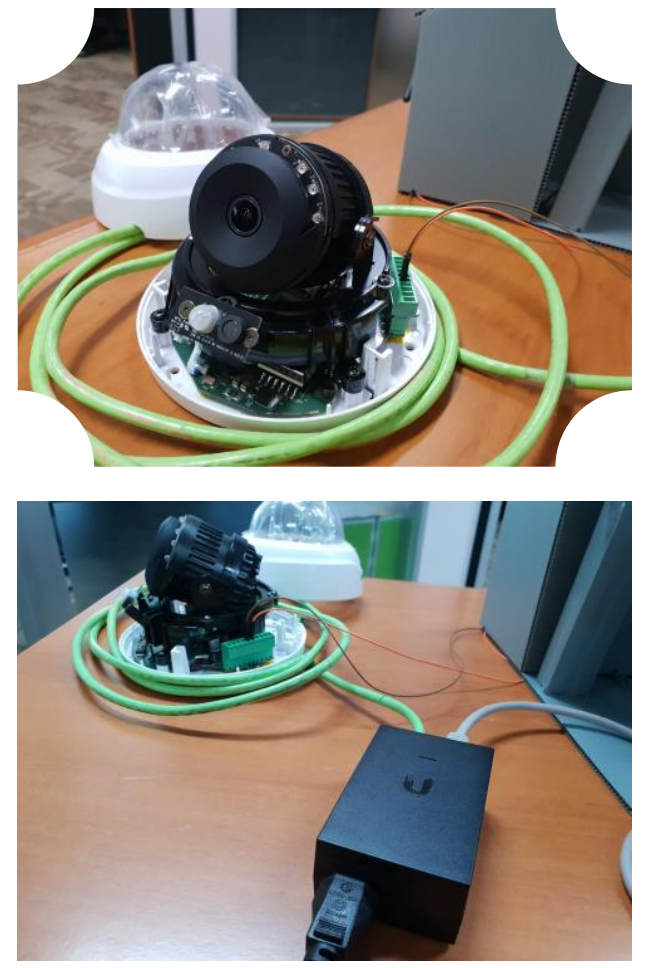

All of these security monitoring systems will be connected to CCTV Vivotek so that they can add evidence to all events that occur.

\section{CONCLUSION}

Based on the results of the implementation of Field Work Practices at PT Astra Graphia Information Technology, the conclusions obtained from the creation of a crime monitoring system project at Bank BRI ATM machines are as follows:

1. Knowing how the industry works at PT Astra Graphia Information Technology.

2. Add insight into embedded systems.

3. Esiduino does not support all sensors that can be used on the Arduino Mega 2560 microcontroller.

4. Real Time Clock Sensor must be synchronized to produce real time time with programs in the example menu on Arduino.

5. Arduino KY-002 Vibration Switch Module does not have a large sensitivity so it is not recommended for this project.

\section{Suggestions}

In implementing Field Work Practices at PT Astra Graphia Information Technology, there are many experiences gained. Based on this experience, the suggestions that can be given are as follows:

1. Do internal meetings with other divisions so there is not much miss communication when the project is done.

2. Using a more industrial microcontroller, such as the Raspberry Pi or Esiduino.

3. Using IoT Gateway which is widely used by industry, for example like Advantech.

4. Look for other forms of crime so that the ATM machine will be safer.

\section{REFERENCE}

[1]
Amelia, M. (2016). Ganjal ATM Pakai Tusuk Gigi, Pria ini Bawa Kabur Uang Rp 29 Juta. Detik:

https://news.detik.com/berita/3229409/ganjal -atm-pakai-tusuk-gigi-pria-ini-bawa-kaburuang-rp-29-juta. [2 Desember 2018]

CaraTekno. (2018). Tutorial Jam Digital Arduino Menggunakan Real Time Clock DS1307. CaraTekno: https://www.caratekno.com/jamdigital-arduino-rtc-ds1307/. $\quad[2$ Desember 2018]

Cisco. (2013). An Introduction to the Internet of Things (IoT). Lope Research, 3.

Dealextream37. (2016). Arduino KY-013 Temperature Sensor Module. Tkkrlab:

https://tkkrlab.nl/wiki/Arduino_KY013 Temperature sensor_module. Desember 2018]

Dealextream37. (2016). Arduino KY-017 Mercury Open Optical Module. Tkkrlab: https://tkkrlab.nl/wiki/Arduino_KY017 Mercury open_optical module. Desember 2018]

Efendi, I. (2017). Jenis atau Type Arduino. Zuhrinet: http://www.zuhrinet.com/jenis-atau-typearduino. [3 Desember 2018]

Fattah, M. I. (2015). Rancang Bangun Prototype Sistem Keamanan untuk Smart Home Monitoring. Bandung: openlibrary.telkomuniversity.ac.id.

IDCloudHost. (2013). Mari Mengenal Apa itu Internet of Things (IoT). IDCloudHost: https://idcloudhost.com/mari-mengenal-apaitu-internet-thing-iot/. [3 Desember 2018] 
[9] Immersa-Lab. (2017). Apa Itu Arduino?. ImmersaLab: http://www.immersa-lab.com/apa-ituarduino.html. [4 Desember 2018]

[10] KlinikRobot. (2014). Gas Sensor (MQ5). KlinikRobot: http://klinikrobot.com/product/gas-detectionsensor/gas-sensor-mq5.html. $\quad$ [4 Dsember 2018]

[11] Lubis, I. (2013). 4 Modus Pembobolan ATM di Indonesia. MetroTempo: https://metro.tempo.co/read/494865/4modus-pembobolan-atm-diindonesia?page_num=4. [12 Desember 2018]

[12] Mujahidin, \& Pahang, N. D. (2012). Rancang Bangun Sistem Informasi Monitoring Perkembangan Proyek Berbasis Web Studi Kasus Di Dinas Bina Marga dan Pemantusan. ejournal.umm.ac.id, 76.

[13] Permana, Y. (2016). Penjelasan Sederhana mengenai Internet of Things. CodePolitan: https://www.codepolitan.com/apa-sih-yangdimaksud-internet-of-thing/. $\quad[12$ Desember 2018]

[14] Prasadan. (2017). Sistem Monitoring SuhuKandang Ayam Dengan LM35 Berbasis Mikrokontroler Arduino Uno. Bali: https://student.unud.ac.id/prasadab/news/324 $\underline{28}$

[15] Pratami, I. R. (2016). Aplikasi Sensor Proximity pada Alat Penyortir Buah Berdasarkan Warna dan Ukuran Bermasis Mikrokontroler ATMega 32. Palembang: http://eprints.polsri.ac.id.

[16] Putra, D. C. (2017). Rancang Bangun Aplikasi Kunci Pintu Otomatis dengan Speech Recognition Berbasis Android. Jawa Timur: http://epints.umm.ac.id.

[17] Putra, S. (2017). Aplikasi Sensor Warna TCS3200 dan ULtrasonik Ping Paralax pada Robot Pencari dan Penganar Target Berbasis Mikrokontroller ATMega 32. Sumatera Selatan: http://eprints.polsri.ac.id.

[18] Sari , W. P., \& Wijaya, R. (2017). Sistem Keamanan Rumah Menggunakan Sensor Getaran dengan Output Suara Berbasis PC Menggunakan Bahasa Pemrograman Visual Basic. Riau: htpp://lppm.upiyptk.ac.id.

[19] Sibarani, F. (2018). Alat Pendeteksi Kebocoran Gas Menggunakan Sensor MQ-2 Berbasis Arduino Uno dan Buzzer. Sumatera Utara: http://repositori.usu.ac.id.

[20] Trisnanda, M. B. (2014). Alat Pendeteksi dan Pengaman Kebocoran Gas Elpiji Menggunakan Sensor MQ-5 Berbasis Mikrokontroler ATMega 8. Palembang: http://eprint.polsri.ac.id.

Ujub. (2015). Jenis atau Type Arduino. Zuhrinet: http://www.zuhrinet.com/jenis-atau-typearduino. [12 Desember 2018]

[22] Utomo, H. T., Winardi, S., \& Kristiana, W. A. (2016). Rancang Bangun Bel Sekolah Otomatis Berbasis Arduino Uno. Surabaya: http://narotama.ac.id.

[23] Wicaksono, G. V. (2017). Stop Kontak Terkendali oleh Android Application via Bluetooth. Salatiga: http://repository.uksw.edu.

[24] Wihagno, D. S. (2017). Sensor Optocoupler sebagai Penggerak Motor Penggulung Plastik Seal pada Rancang Bangun Cup Sealer Otomatis. Sumatera Selatan: http://eprints.polsri.ac.id. 